\title{
DRD2 Gene
}

National Cancer Institute

\section{Source}

National Cancer Institute. DRD2 Gene. NCI Thesaurus. Code C19895.

This gene plays an inhibitory role in the regulation of adenylyl cyclase activity. 